\title{
Chechens: Freedom Fighters or Terrorists?
}

\author{
CHAIM SHIN A R \\ Hazamir St. 22/23, Kiryat Ono, 5550722, Israel. Email: chaimshinar7@gmail.com
}

This article seeks to answer the following research questions: (1) why have the Chechen leaders become extremely religious, whereas at the beginning of the RussoChechen conflict in the 1990s, they were predominantly secular; and (2) what led the Chechens to use terrorism to fulfil their aspirations for complete independence from Russia. The article shows that the flow of foreign religious terrorists into the republic, as well as financial assistance to the Chechen population and its fighting leaders, turned the Chechen leaders from predominantly secular ones into extremely religious ones. At the same time, the traumatization of the Chechens by Russia's disproportionate use of force against civilians was the reason that Chechens use terrorism against the Russian forces.

The foaming Terek rushes on,

His stony shores between;

And there the wicked Chechen creeps,

And whets his dagger keen.

(Cossack Lullaby by Mikhail Lermontov, 1840)

\section{Terrorism; Definitions}

'It is impossible to agree upon a universal definition of terrorism. The term is one of the most politicized and contested concepts in the modern era,' writes James Hughes. ${ }^{1}$ Michael Gross claims:

Legal asymmetry points to the disparate status of the parties to the conflict. On one hand, sovereign nation-states are the building blocks of the international order and the only legitimate purveyor of armed force. They confront, on the other hand, an array of nonstate actors that include guerrilla organizations or militias representing national groups and wielding some governmental authority. ${ }^{2}$

Matthew Janeczko defines terrorism as 'Any intentional act of violence against civilian targets that do not have the authority or ability to alter government policy, with the purpose of attaining political aims.' 'By this logic,' he continues, 'civilians and government agents alike can commit acts of terror, while attacks directed against 
the government, the military, or government security forces, should not be seen as acts of terrorism. ${ }^{3}$ Modern academic definitions of terrorism identify the act as illegitimate not because of the end to which it is applied, but because of what it entails as a means of violence, namely, that it implies violent action against civilians or noncombatants (Ref. 1, p. 294). Terrorism has always been and will always be the method of the powerless, possessed by powerful passions. Their opponents are the modernist and/or postmodernist powers who rely on rational planning, huge bureaucracies, and technology in waging wars - but who often lack passion, or even a clear vision of what they are fighting for. ${ }^{4}$ Chechnya epitomizes the old saying that 'one man's terrorist is another man's freedom fighter'. 5

\section{Chechnya and Russia}

Chechnya is a highly mythologized region in traditional Russian imagination. This stems largely from the writings of nineteenth-century Russian poets and novelists: the poets Alexander Pushkin and Mikhail Lermontov, the novelist Leo Tolstoy, and the playwright Alexander Griboyedov presented Chechnya in a romanticized way, portraying the Chechen people as lone and noble fighters. The Caucasian wars became a prominent theme in Russian culture, and the Chechens a symbol of the heroic struggles of the mountain peoples to preserve their independence. ${ }^{6}$

A number of factors explain the particularly sharp tensions in relations between Moscow and Grozny, the capital of Chechnya. First there is an underlying legacy of antagonistic group histories dating from the Russian conquest of the Caucasus and the particularly stubborn resistance to Russian imperial expansion. The region was conquered by Tsarist Russia, whose armies took three decades to overcome the resistance of the guerrilla warriors. Ever since, Chechnya has erupted into revolt whenever the Russian grip weakened. In 1834, Shamil provided the Chechens with a way of defending their way of life against the Russian Offensive, when he declared,

our perception, Islam and the traditions of our mountain way of life sanctify a life of freedom to all peoples, and safeguard the dignity of a free man. ... We did not fight against the Russians or the Christians: We fought for our right to freedom. ${ }^{7}$

The Soviets were averse to all forms of religion, but they took a special dislike to Islam: Soviet propaganda proclaims the advent of a mythical 'Homo Sovieticus'. A Soviet Russian remains a Russian, a Soviet Muslim simply a Muslim, not a 'Homo Islamicus'. Abandoning ideology, in the 1920s Soviet experts increasingly came to see Chechnya as a special case: a 'bandit nation' where religious and cultural customs enhanced the likelihood of fifth columnist activity. ${ }^{8}$

In the 1980 s, 200,000 people, of a population of about one million, were unemployed in Chechnya, while the Soviet Union still existed, where unemployment was not supposed to exist. To make matters worse, Chechens were treated as second-class citizens during the Soviet era and were generally not allowed to participate in higher education or assume high-ranking positions in the government. Russian popular stereotypes of the Chechens had been manipulated in such a way as to replace a 
generally positive perception of the noble and free mountain man into, first, a dangerous and bloodthirsty criminal, and then into a crazed and fanatical terrorist of Islamic fundamentalist persuasion. Chechen society is indeed marked by a martial spirit, linked to a very strict code of honour and dignity: every man is considered first and foremost a warrior. His weapons are his dearest possessions. On the other hand, Marsho - freedom - is a central concept in both Chechen culture and the Chechen psyche. Although Chechen nationalists attach to it modern political connotations, traditionally its meaning went far beyond that of either the Western or Islamic connotation of the word. In the Chechen language, the word also contained the connotation of 'peace' and 'well-being'?

\section{The Struggle for Independence}

On 26 November 1990, the Supreme Council of Chechen-Ingush ASSR adopted the 'Declaration of State Sovereignty of the Chechen-Ingush Republic'. This declaration was part of the reorganization of the Soviet Union. This new treaty should have been signed in 22 August 1991, and would have transformed 15 republic states into more than 80. The 19-21 August 1991 Soviet coup d'état attempt led to the abandonment of this reorganization. With the impending dissolution of the Soviet Union in 1991, an independence movement, initially known as the Chechen National Congress, was formed and led by ex-Soviet Air Force general and new Chechen President, Dzhokhar Dudayev. It rallied for the recognition of Chechnya as a separate nation. This movement was ultimately opposed by Boris Yeltsin's Russian Federation, which first argued that Chechnya had not been an independent entity within the Soviet Union - unlike the Baltic, Central Asian, and other Caucasian States - but was part of the Russian Soviet Federative Socialist Republic and hence did not have the right to secede under the Soviet constitution. Second, the argument went that other republics of Russia, such as Tatarstan, would consider seceding from the Russian Federation if Chechnya were granted this right. Third, Chechnya was a major hub in the oil infrastructure of the Federation and hence its secession would hurt the country's economy and energy access. Still, the fact that after the dissolution of the Soviet Union, Chechnya, unlike Tatarstan, had an external border made secession a real possibility and a sovereign or independent existence appeared more viable.

The struggle over the political status of Chechnya triggered by the growing wave of national self-assertion throughout the region resulting from Gorbachev's reforms was shaped by a long history of Russian-Chechen conflict whose origins date back to the Caucasian wars of the eighteenth and nineteenth centuries. Moscow's policy has been to reintegrate Chechnya into the political structures of the Russian Federation and turn day-to-day control over to loyal, handpicked Chechen leaders. For the Russian interventionists, the secession of Chechnya posed a threat to Russian statehood as it might undermine the territorial integrity and sovereignty of Russia, and thus it was to be prevented at all costs. 
James Hughes claims that

For the Chechen secessionists, their right to self-determination and independence from the former USSR, the colonial power, and its successor state, the Russian Federation, is paramount and legitimate. The greatest test for international norms on secession arises in cases where there is no agreement between the parties and where the entity aspiring to self-determination falls outside the administrative category recognized under the legal principle. Both factors apply in the case of the conflict in Chechnya. The collapse of the USSR was treated, in effect, as a case of decolonization. The conservatism was reinforced by the predominance of Western interests in shoring up the Yeltsin regime to prevent instability in Russia, and policy caution in the wake of the Soviet collapse. ${ }^{10}$

\section{The Chechen Wars}

In December 1994, Yeltsin sent the Russian army to Chechnya in order to 'restore constitutional order' there. After the initial campaign of 1994-1995, culminating in the devastating Battle of Grozny, Russian federal forces attempted to seize control of the mountainous area of Chechnya but were pushed back by Chechen guerrilla warfare, despite Russia's overwhelming manpower, weaponry and air support. The resulting widespread demoralization of the federal forces and the opposition of the Russian public to the conflict led Boris Yeltsin's government to declare a ceasefire with the Chechens in 1996 and sign a peace treaty a year later that included the withdrawal of Russian forces. Russia's reckless and disproportionate use of force against civilians in Chechnya at times had been genocidal, in particular its reliance on the indiscriminate bombardment of civilian areas and the well-documented cases of massacres. Sensibly, neither the Russians nor the Soviets wished physically to exterminate the Chechens, but rather to resettle and re-educate them en masse. Still, the brutality employed against them as a people has been such that the Chechens find it difficult to distinguish 'assimilation' from 'genocide'. ${ }^{11}$ Accepting Russian rule was to the Chechens more than losing freedom in the Western sense of the word: it was losing one's manhood and - more important - one's soul. The Chechen victory over the Russian Federation in the first war in 1994-1996 has been considered a remarkable military victory. However, a weak economy, high unemployment and criminality caused the young nation to fall into a state of lawlessness and radicalism, eventually causing it to suffer a defeat to the Russians in the second war, which began in 1999 (Ref. 1, p. 307; Ref. 7, p. 59).

After the Russian withdrawal from Chechnya in 1996, armed gangs stepped up a lucrative trade in hostage taking and assassination. The situation was described in the 1998 and 1999 annual reports of the Assistance Group of the OSCE in Chechnya as one where 'crime, unrest and acts of terrorism have acquired endemic proportions, adding to a volatile political situation and a general breakdown of law and order.' According to the OSCE officials, Chechnya was a 'hotbed of crime and terror'. ${ }^{12}$

Putin, in 1999, as Yeltsin in 1994, sent the Russian army to Chechnya to 'restore constitutional order'. The results, however, brought precisely the opposite. Rather than a place of constitutional order, Chechnya has for years been a lawless ghetto. 
Here, soldiers and policemen have been able to loot, rape and murder - almost certain of escaping punishment. Chechen rebel factions have blown up civilians who happen to be around military targets. Chechens in irregular, pro-Kremlin units torture and kidnap fellow Chechens - often-former rebel comrades in arms. ${ }^{13}$

Litvinenko and Felshtinsky argued that the two Chechen wars (1994 and 1999) were preceded by terrorist acts in Russia. These terrorist acts were, it is claimed, committed by the Russian security agencies that replaced the Soviet KGB. Their purpose was to justify the invasion of Russian forces into Chechnya. ${ }^{14}$ In her testimony to the US Senate Committee on Foreign Relations in November 1999, Elena Bonner, the chair of the Andrei Sakharov Foundation, summarized the domestic political causes of the war by stating: 'The first war was needed in order to re-elect President Yeltsin. [and the second war] ... was needed to raise the standing in the polls of ... Vladimir Putin, whom President Yeltsin publicly endorsed as his chosen successor.' In addition, 'for the presidential administration, for government ministers, and for Duma politicians, the war [was] needed to resuscitate patriotic slogans and divert the public's attention from the corruption and financial scandals to the enemyin this situation, the Chechens. 15

\section{The Absence of Chechen Native Communist Leadership}

According to Moshe Gammer, one of the major social successes of the Soviet regime was the creation of a single homogeneous Soviet elite in all parts of the USSR. This elite was intensely Sovietized and Russified, aloof from its own people and strongly tied to Moscow. Gammer claims that the major obstacle to a Russo-Chechen compromise, and the major cause for the wars in Chechnya, was the absence of a Chechen partokratiia - a Chechen elite Sovietized and Russified with strong ties to Moscow. ${ }^{16}$ That is also Richard Sakva's argument:

... the local Communist leadership was largely 'Chechenized' only in the last years of Soviet power. This was too late to develop a substantial ethnic Chechen communist elite in the republic, and by the time this elite came to power the Soviet leadership was already disintegrating.

'Paradoxically,' wrote Richard Sakwa, 'the repression of the early Soviet years that culminated in the 1944 deportation destroyed modernized groups like the intelligentsia and Party bureaucracy, and thus served to accentuate the traditional social order and values. ${ }^{17}$ According to James Hughes:

As a consequence of Soviet modernization policies, an urbanized and secularized stratum emerged to dominate the Chechen elite by the late Soviet era. This upwardly mobile stratum felt constrained by the ethnic privileging of Russians and other Slavs in the republic. (Ref. 12, p. 22)

Historian Alexander Statiev has persuasively argued that the net effect of Soviet counter-insurgency policies in Soviet borderland regions in the interwar period helped to forge a unified anti-Soviet movement from among these numerous 
disparate 'bandit groups'. The defectors in the year 1942 to the Germans included a large proportion of Chechen native leadership in Chechnya-Ingushetia (Ref. 8, p. 291).

\section{How did Chechnya become Linked to Terrorism}

The Second World War and the two Chechen wars rendered many towns, including the capital Grozny, virtually uninhabitable. There was almost universal unemployment among young Chechen men. Sufficient reconstruction aid from Moscow never materialized, as federal and regional bureaucrats pilfered those resources. ${ }^{18}$ The miserable socio-economic situation provided fertile ground for criminal acts, radical ideologies, and Islamic recruitment. According to Amandine Regamey et al., the lack of economic prospects and widespread corruption can explain the attraction exerted by Islamic discourse and projects. ${ }^{19}$ The conditions that gave root to the rise of radical Islam in Chechnya were in the first instance the disproportionate violence used by the Russian armed forces against Chechens during the first campaign. The second instance was Russia's blockade of Chechnya in the post-war period of 1997-1999.

The atrocities committed by the Russian army during the Russian invasion in 1994 were the major cause of the spread of radical Islamism in Chechnya, as they created the opportunity and location for foreign volunteers to meet, train, finance, and influence local combatants who joined the ranks of the radicals. Backed by prominent warlords, with their ideas embraced by several political actors, as well as with foreign money pouring into Chechnya, transnational Islamist actors with a Salafi-jihadist ideology ${ }^{20}$ gradually gained an increased role in Chechen politics.

The Wahhabis ${ }^{21}$ recruited among young, unemployed men, who had never known peace, who had grown up in war and knew nothing but war. Those that chose to follow the principles of Wahhabism or enlist in their troops were offered money. Chechen president Maskhadov was overwhelmed by socioeconomic challenges, abandoned by the Russian Federation and the international community, and compromised by his inability to monopolize the fractured military forces that fell increasingly under the influence of Wahhabi extremists who provided ideological and economic support. ${ }^{22}$ Dzhabrail Gakaev argues that the introduction in Chechnya of Salafi-jihadist ideology has torn Chechen society apart, ${ }^{23}$ as a vast majority of Chechen warriors in Chechnya itself and beyond have argued that they engage in a war for freedom, not in terrorism. The actual goals of the Chechen rebels are a matter of much debate. On one hand, there are arguments that the Chechen rebels are separatists attempting to achieve independence from Russia and that this attempt began with the dissolution of the Soviet Union in 1991. On the other hand, it is argued that Chechnya is part of a jihad whose goal is to alleviate the suffering of Muslims at the hand of the Russians. In summary, Chechen warriors invoke both jihadist and separatist ideologies for their acts. ${ }^{24}$

Politkovskaya claims that the Chechen struggle is due perhaps to 'a special emotional state known only to people who have been subjected to genocide in the past:' 
The first generation of Chechen fighters consisted of volunteers who rose in the patriotic defense of their homeland. They fought not only for themselves and their families but also for the ancestors who perished in the deportation of 1944 and in the Caucasus war of the nineteenth century. ... The 'never again!' sentiment that reduces the whole world to the dilemma of survival. It provided the extraordinary determination and moral edge to the Chechen fighters in the first war. ${ }^{25}$

The politics and practices of many rebel camps in Chechnya during the 1990s transitioned from a major emphasis on nationalistic aims into terrorist bases with a more international religious agenda, similar to those operating in Afghanistan during the Taliban regime. By the turn of the twenty-first century, the radical fighters were well on their way to transforming Chechnya and the North Caucasus into a springboard for attacks into Russia and Europe. Although the Chechen conflict began as an indigenous national movement, it was not long before resistance leaders took up the banner of Islam. The concept of applying religion to justify going to war is a transnational one, as it exists in most theological traditions and is, in fact, one of the bases for the modern international law of war. Religion has dramatically altered the nature of civil wars as well as the intensity with which outsiders intervene to influence their outcome. Civil wars with religion as a component are peculiarly dangerous, in part because they are so susceptible to becoming transnational. ${ }^{26}$

With radical leaders and the political leadership both wrapping themselves in the cloak of Islam, the Chechen conflict became ripe for foreign jihadists to take up the cause. In the autumn of 1991, Dzhokhar Dudayev, the Chechen leader, said that Islamic fundamentalism in Chechnya represented no danger, but maintained that hostile actions by Russia could push Chechen nationalism onto a more extremist, Islamic path (Ref. 9, p. 241; Ref. 27, p. 422). Irina Mukhina argues that at the very least, the ideology of jihad serves as a cover for less religious and more ruthless goals, espoused by leaders that are more pragmatic as a means to manipulate young and religiously committed terrorist acts. ${ }^{27}$

As the Chechen war continues and terrorism mounts, the Russian government has responded by centralizing power, harshly cracking down on innocent Muslims, and increasingly violating Muslims' political, civil and human rights, making the latter more open to calls for secession and Islamism. ${ }^{28}$ Svante Cornell, discussing the Russo-Chechen conflict in 2005, writes, 'Russia's war in Chechnya, so far from countering terrorism, is inevitably creating extremism and sowing the seeds of terrorism. ${ }^{29}$ The terrorism-sponsored organizations in Chechnya were clearly nationalistic and independent-oriented in their outlook, but as foreign funding flowed into the country during the 1990s rewarding those who adopted the militant Wahhabi ideology, these groups have become increasingly religiously oriented as well. During the chaotic period of de facto Chechen independence in 1996-1999, the radical Islamists under the leadership of Shamil Basayev and Amir Khattab were confined to a small area in south-eastern Chechnya. President Maskhadov in 1999 even warned Moscow of their possible intentions and requested help to combat them, but received no response (Ref. 25, p. 444). During Russia's second assault on Chechnya, in 1999, most of the little republic's first wave of independence-seeking leaders, who had 
espoused secular nationalism, was killed or defected to the Russian side. Militant Islamists, seeking to create a Caucasus-wide 'caliphate', took over the movement and found tactical inspiration, as well as material support, with Middle Eastern Islamist terror networks such as Al-Qaeda. The Islamist insurrection has since spread to neighbouring republics, especially Ingushetia and Dagestan. Chechen-led terrorists have struck repeatedly in the Russian heartland, notably a mass hostage-taking at a downtown Moscow theatre in 2002 that killed 130 people, and a horrific school siege in Beslan, North Ossetia, that killed 330 people, half of them children. A double suicide bombing by 'black widow' terrorists - wives of rebels killed by Russian security forces - left 40 people dead in a 2010 Moscow metro attack and another suicide bombing at Moscow's Domodedovo airport the next year left 35 people dead. $^{7}$ Beginning in 1999, an organized terrorist element evolved in Chechnya within the larger Chechen separatist movement fighting to secede from Russia. Led primarily by Shamil Basayev (1965-2006) and comprising both native and foreign personnel, these groups were responsible for many brutal terrorist attacks in Russia, including such highly publicized atrocities as the 2002 theatre siege in Moscow and the 2004 Beslan massacre. ${ }^{30}$

Matthew Janeczko, explaining the suicide bombings by the 'black widows' claims that

To those recently exposed to the violent death or injury to a loved one, a jihadi ideology provides a simple and culturally acceptable psychological coping method to deal with the stress and trauma of war and personal loss. The level of 'psychological traumatization' is likely the most significant motivational factor, which attracted the bombers into embracing radical religious and terrorist ideologies and led to individual terrorist acts. ... In many ways, religion 'gives meaning to suffering', both to personal suffering, and to the suffering of others, who suffered otherwise without reason (Ref. 3, pp. 438-439).

\section{The Beslan Tragedy; September 2004}

Dunlop's findings lead the reader to some very uncomfortable conclusions: that at Beslan the Russian special forces not only started the firing at the school, but that they employed thermobaric Shmel' flamethrowers and tanks in the assault to free the children trapped inside the gymnasium. While at Dubrovka, the Federal Security Service (FSB), it is implied, had 'staged' the hostage-taking crisis to undermine peace processes that were promising a genuine political settlement negotiated with the Chechen separatist leadership. ${ }^{31}$

Answering the criticism, Basayev not only claimed responsibility for the operation at Beslan but, subsequently, even apologized publicly for his miscalculation of Putin's response, asserting that a school was selected because even the Russian authorities would think twice about attacking buildings crammed full of children. A few weeks later, after the Beslan siege, the Chechen resistance website carried the following message: 
There is not and there cannot be any justification for people who raise their hands against what is most holy to us - the lives of defenseless children. There are no words to express the full depth of our shock at what has happened ... We deeply regret that the repercussions of the inhumane war against Chechnya have come to our brother state Ossetia in such a tragic manner.

Basayev stated that he never intended to kill children, but only hold them as hostages to force the withdrawal of the Russian troops from Chechnya. Speaking to ABC News Nightline, on 28 July 2005, Basayev drew a similar comparison saying that the children killed in Beslan were only a small percentage of those killed in Chechnya. ${ }^{32}$ Efforts by the Russian parliament to assert oversight power over the security agencies, through investigations of their actions in the Beslan crisis, were effectively blocked. $^{33}$

\section{Conclusion}

In 2004, Putin, by handpicking a loyal Chechen leader, Akhmad Kadyrov, believed that Chechnya should fall into the day-to-day control of the Russian Federation. Even as some writers claim that Chechnya now is a sovereign state, ${ }^{34}$ the wars of the Chechens have not yet led to the liberation of the country from Russian control. The belief that Chechnya is de facto independent from Russia and that Ramzan Kadyrov, Akhmad Kadyrov's son, is independent from the Kremlin is merely a delusion.

Ramzan Kadyrov, a brutal dictator, can only afford to do what his 'godfather', President Vladimir Putin, allows him to do; he is well aware of the fact that once Russian military support vanishes, thousands of people whose relatives and friends have been murdered will be waiting to take revenge and tear Kadyrov to pieces. ${ }^{35}$ In 2009, the American organization Freedom House included Chechnya in the 'Worst of the Worst' list of most repressive societies in the world, together with Burma, North Korea, Tibet, and others. ${ }^{36}$ As Politkovskaya observed: 'A little dragon has been raised by the Kremlin. Now they need to feed it. Otherwise, it will spit fire. ${ }^{37}$ Kadyrov claims that he is Putin's loyal 'footsoldier', and he has managed to get Moscow to pay for it: more than $80 \%$ of the Chechen budget comes from the Russian federal treasury. ${ }^{38}$

\section{References and Notes}

1. J. Hughes (2007) The Chechnya conflict: Freedom fighters or terrorists? Demokratizatsiya, 15(3), p. 293.

2. M.I. Gross (2010) Moral Dilemmas of Modern War: Torture, Assassination, and Blackmail in an Age Asymmetric Conflict (New York: Cambridge University Press), p. 12.

3. M. Janeczko (2014) 'Face with death, even a mouse bites': Social and religious motivations behind terrorism in Chechnya. Small Wars and Insurgencies, 25(2), p. 433.

4. S.G. Mestrovic (1999) Series Editor's statement. In: S. Knezys and R. Sedlickas, (Eds) The War in Chechnya (USA: Texas A\&M University Press), p. xiv. 
5. S.E. Cornell (2003) The war against terrorism and the conflict in Chechnya: A case for distinction. Political Science Complete, 27(2), p. 167.

6. G.W Lapidus (1998) Contested sovereignty: The tragedy of Chechnya. International Security, 23(1), p. 8; see also D Trenin, A Malashenko and A. Lieven (2004) Russia's Restless Frontier: the Chechen Factor in Post-Soviet Russia (Washington, DC: Carnegie Endowment for International Peace).

7. D.M. Mahomedov (2002) Shamil's testament. Central Asian Survey 21(3), quoted in J. Swirszez (2009) The role of Islam in Chechen national identity. Nationalities Papers, 37(1), p. 67 (emphasis in original quote); see also F. Weir (2013) Chechnya: How a remote Russian republic became linked to terrorism. Christian Science Monitor, 19 April, ISSN: 0882-7729.

8. J. Burds (2007) The Soviet war against 'Fifth Columnists': The case of Chechnya, 1942-4. Journal of Contemporary History, 42(2), pp. 282-283; see also A. Bennigsen and M. Broxup (1983) The Islamic Threat to the Soviet State (Beckenham, Kent: Provident House).

9. M. Gammer (2006) The Lone Wolf and the Bear: Three Countries of Chechen Defiance of Russian Rule (London, UK: C. Hurst \& Co.), pp. 5-6; see also K. Hertog (2005) A self-fulfilling prophesy: The seeds of Islamic radicalization in Chechnya. Religion, State \& Society, 33(3), p. 248; J. Russell (2007) Chechnya Russia's 'War on Terror' (New York and Canada: Routledge), p. 92; M.B. Shishani-al (2007) The rise and fall of Arab fighters in Chechnya. The Jamestown Foundation, p. 7.

10. J. Hughes (2007) Chechnya: From Nationalism to Jihad (Philadelphia, USA: University of Pennsylvania Press), pp. 15. 29; see also A. Matveeva (2007) Chechnya: Dynamics of war and peace. Problems of Post-Communism, 54(3), p. 3; G.W. Lapidus (1998) Contested sovereignty: The tragedy of Chechnya. International Security, 23(1), p. 8.

11. The test of systematic indiscriminate attacks on non-combatants refers to the Geneva Conventions and Protocols' concern for the protection of civilians and non-combatants, see p. Wilkinson (2011) Terrorism versus Democracy: The Liberal State Response (Routledge, USA and Canada), p. 62.

12. In J. Hughes (2001) Chechnya: The causes of a protracted post-Soviet conflict. Civil Wars, 4(4), p. 34.

13. S. Smith (2006) Allah's Mountains: Politics and War in the Russian Caucasus (London: I.B. Tauris), p. xvii; J. Hughes (2007) The Chechnya conflict: Freedom fighters or terrorists? Demokratizatsiya, 15(3), p. 34.

14. According to Litvinenko and Felshtinsky, before the first Chechen war, an explosion on the river Yauza was the pretext to the invasion into Chechnya. The explosion on 18 November 1994, took place on a railroad track crossing the river Yauza in Moscow. The explosion was carried out by Captain Andrei Shelenkov whose body was found nearby after the explosion. Litvinenko and Felshtinsky also claim that the September 1999 Russian apartment building terror-bombing campaign used hexogen (i.e. cyclonite; RDX) as the explosive and was blamed on Chechen terrorists despite there being not the slightest shred of evidence that Chechens were behind it. It later turned out that the bombings were done by the Russian security agencies themselves caught by local police and citizens in the city of Ryazan planting live explosives (i.e. hexogen) with live detonators in an apartment building. In A. Litvinenko and Y. Felshtinsky (2007) Blowing up Russia: The Secret Plot to Bring Back KGB Terror (New York: Encounter Books); see also: D. Satter (2002) The shadow of Ryazan: Who was behind the 
strange Russian apartment bombing in September 1999? Russian and Eurasian Studies, 19 April, http://www.sais-jhu.edu/depts/res

15. E. Bonner (1999) Statement of Elena Bonner for the Senate Foreign Relations Committee. Turkistan, 3(254). In O. Ashour (2004) Security, oil, and internal politics: The causes of Russo-Chechen conflicts. Studies in Conflict and Terrorism, 27, p. 138.

16. M. Gammer (2005) The road not taken: Daghestan and Chechen independence. Central Asian Survey, 24(2), p. 98.

17. R. Sakwa (2005) Introduction: Why Chechnya? In R. Sakwa (Ed.), Chechnya: From Past to Future (London, UK: Anthem Press), pp. 3, 7.

18. In 18 August 1997, Yeltsin said that while Moscow had allocated $\$ 138$ million to Chechnya this year, only \$21 million had reached the National Bank of Chechnya. 'The devil only knows where the money is going,' said Mr Yeltsin after a 90-minute meeting with Chechen President Aslan Maskhadov in the Kremlin. In P. Ford (1997) Only \$21 million of the \$138 million committed eventually reached Chechnya. Christian Science Monitor, 19 August.

19. A. Le Huerou, A. Merlin, A. Regamey and E. Sieca-Kozlowski (Eds) (2014) Chechnya at War and Beyond (New York: Routledge), p. 2.

20. The terms 'Salafist jihadist' and 'Jihadist-Salafism' were coined by scholar Gilles Kepel in (2002) to describe 'a hybrid Islamist ideology' developed by international Islamist volunteers in the Afghan anti-Soviet jihad who had become isolated from their national and social class origins. In G. Kepel (2002). The Trail of Political Islam (Cambridge, MA: Harvard University Press), pp. 219-222.

21. A religious movement or branch of Sunni Islam. It has been variously described as 'ultraconservative', 'austere', 'fundamentalist', 'puritan' and as an Islamic 'reform movement' to restore 'pure monotheistic worship' by scholars and advocates. In Analysis Wahhabism (2014) PBS Frontline, 13 May.

22. E. Gilligan (2009) Book review: Hughes, James (2007) Chechnya: From Nationalism to Jihad (Philadelphia: University of Pennsylvania Press). Political Science Quarterly, 124(1), p. 210; see also S.E. Cornell (2003) The war against terrorism and the conflict in Chechnya: A case for distinction. Political Science Complete, 27(2), p. 174; M.F. Karim (2013) How ethnic civil war transforms into religious civil war: Evidence from Chechnya. CEU Political Science Journal, 8 (1), p. 69; M. Gammer (2013) Empire and mountains: The case of Russia and the Caucasus. Social Evolution and History, 12(2), p. 133.

23. D. Gakaev (2005) Chechnya in Russia and Russia in Chechnya. In: R. Sakwa, (Ed.) Chechnya: From Past to Future (London: Anthem Press), p. 27.

24. I. Mukhina (2005) Islamic terrorism and the question of national liberation, or problems of contemporary Chechen terrorism. Studies of Conflicts \& Terrorism, 28(March), p. 523; see also L. McCartan, A. Masselli, M. Rey and D. Rusnak (2008) The logic of terrorist target choice: An examination of Chechen rebel bombings from 1997-2003. Studies in Conflict and Terrorism, 31, p. 76; D. Gakaev (2005) Chechnya in Russia and Russia in Chechnya. In: R. Sakwa (Ed.), Chechnya: From Past to Future (London: Anthem Press), p. 27.

25. A. Politkovskaya (2003) A Small Corner of Hel: Dispatches from Chechnya (Chicago: The University of Chicago Press), p. 20.

26. T. Shah, M.D. Toft and D. Philpott (2011) God's Century: Resurgent Religion and Global Politics (New York: W. W. Norton), p. 157; see also A. Speckhard and K. Ahkmedova (2006) The making of a martyr: Chechen suicide terrorism. Studies of Conflict and Terrorism, 29, p. 446; G. Garner (2013) Chechnya and 
Kashmir: The jihadist evolution on nationalism to jihad and beyond. Terrorism and Political Violence, 25, p. 419; J. Fox and S. Shmuel (2006) Religion in World Conflict (New York: Routledge), p. 8.

27. I. Mukhina (2005) Islamic terrorism and the question of national liberation, or problems of contemporary Chechen terrorism. Studies of Conflicts \& Terrorism, 28, p. 516.

28. G.M. Hahn (2005) The rise of Islamist extremism in Kabardino-Balkariya. Demokratizatsiya, 13(4), p. 545.

29. S.E. Cornell (2005) The war in Chechnya: A regional time bomb. Global Dialogue, 7(3/4), p. 54, 59.

30. T.S. Wittig (2009) Financing terrorism along the Chechen-Georgian border, 1999-2002. Global Crime, 10(3), p. 248.

31. J.B. Dunlop (2006) The 2002 Dubrovka and Beslan Hostage Crises: A Critique of Russian Counter-terrorism (Stuttgart: Ibidem-Verlag); In: J. Russell (2007) Review article. Chechnya: Russia's 'War on Terror' or 'War of Terror'. EuropeAsia Studies, 59(1), p. 166.

32. A. Speckhard and K. Ahkmedova (2006) The making of a martyr: Chechen suicide terrorism. Studies of Conflict and Terrorism, 29, pp. 440 and 481; see also J. Russell (2009) The geopolitics of terrorism: Russia's conflict with Islamic extremism. Eurasian Geography and Economics, 50(2), p. 192; see also E. Souleimanov and O. Ditrych (2008) The internationalization of the RussianChechen conflict: Myths and reality. Europe-Asia Studies, 60(7), p. 1212.

33. T.F. Remington (2009) Putin, parliament, and presidential exploitation of the terrorist treat. The Journal of Legislative Studies, 159(2-3), p. 219.

34. A. Koch (Ed.) (2015) 'In Chechnya, Russian laws are not working', Facebook (Alfred Koch - deputy prime minister under President Yeltsin, 17 March - 13 August 1997).

35. M. Akhmadov (2013) Voice of the republics. Index on Censorship, 42(2), p. 147.

36. Worst of the worst: The world's most repressive societies. Freedom House, March 2009.

37. In: J. Russell (2011) Kadyrov's Chechnya - template, test or trouble for Russia's regional policy? Europe-Asia Studies, 63(3), p. 509.

38. M. Galeotti (2016) Ramzan Kadyrov: The Kremlin's public frenemy number one. www.ecfr.eu/.../commentary_kadyrov_the_kremlins_public_frenemy_num ber_one5081.

\section{About the Author}

Chaim Shinar holds an Israel Open University BSc in Natural Sciences and an MA degree in Interdisciplinary Democracy Studies. His research is on current political and economic development in Russia. Chaim Shinar is an independent scholar. 